\title{
Reducing environmental pollution caused by construction plant
}

\author{
Roy Morledge ${ }^{1}$ \\ Frank Jackson ${ }^{2}$
}

\footnotetext{
${ }^{1}$ Roy Morledge is Professor of Construction Procurement at The Nottingham Trent University

${ }^{2}$ Frank Jackson is a Contracts Procurement Manager at the Environment Agency
} 
Roy Morledge is Professor of Construction Procurement at The Nottingham Trent University, where he is Director of Graduate Studies for the Faculty of Construction and the Environment. After many years as a surveyor for construction firms he joined the University where his current responsibility includes the Construction Procurement Unit which is focused upon research and consultancy in the field of construction procurement. He has authored many papers in his field and advises institutions, corporate organisations and government agencies.

Frank Jackson is a contracts Procurement Manager at The Environment Agency of England and Wales. Based in Warrington Cheshire, he has particular responsibility for all civil engineering and flood-defence procurement within the North West Region and national responsibility for environmentally considerate lubricants. He has considerable experience in both the public and private sectors and contributes towards the long-term strategic review of construction activity currently being undertaken throughout the Agency. 


\section{Abstract:}

Quantifiable data produced in a national report by the Environment Agency of England and Wales entitled 'Water pollution incidents in England and Wales 1997' and published by the Stationery Office in 1998, identifies that of over 3,723 substantiated pollution incidents across England and Wales in 1997. Within the generic sector classed as 'Industry' the construction industry was the most frequent polluter responsible for $22 \%$ of all substantiated water-related pollution incidents in that sector. The report also identified that a significant number (28\%) of all substantiated pollution incidents across England and Wales are directly attributable to mineral-based fuels and oils many of which are used extensively within the construction industry.

This paper seeks to locate the possible causes and effects for some of that oil-based pollution, discuss the issues and identifies a unique and radical Client-motivated solution within the UK to reduce and mitigate the undesirable impacts upon the environment. Evidence produced by the oil industry shows the enormous amount of one particularly aggressive pollutant -hydraulic oil, - which remains annually, unaccounted for. Hydraulic oil is used in most tracked earthmoving machinery; the sort of machinery most closely associated with construction work carried out near to watercourses.

Biodegradable hydraulic oil is much more considerate to the environment, but is more expensive and not usually installed in new plant and machinery. The paper argues that on a life cycle basis the use of biodegradable oil is viable and feasible and that there are many external factors that make its usage desirable.

Keywords: pollution; construction; hydraulic oil; biodegradability; environment 


\section{Reducing environmental pollution caused by construction plant.}

\section{Roy Morledge and Frank Jackson}

Roy Morledge is Professor of Construction Procurement at The Nottingham Trent University Frank Jackson is a Contracts Procurement Manager at the Environment Agency

\section{Background to the problem.}

The Environment Agency for England and Wales is a non-departmental publicly funded body. It was formally created on 8 August 1995 by the Environment Act 1995 and took up its statutory duties at vesting on 1 April 1996 created in April 1996.

The Agency is ultimately responsible to Parliament through the Secretary of State for the Environment, Transport and the Regions. It has a range of functions to do with regulation, management, monitoring and understanding all aspects of the environment and of the processes which affect it.

The principle aim of the Agency is to protect and enhance the environment of England and Wales taken as a whole and to make a contribution towards attaining the objective of achieving sustainable development that Ministers consider appropriate.

In 1997 the Agency responded to over 30,000 reports of water pollution incidents in England and Wales of which $64 \%(19,571)$ were substantiated - i.e. a pollution incident had occurred. (Environment Agency 1997) This is not an uncommon figure, because since 1991 the average number of substantiated incidents has been running at about 23,000 per year. 
Some 194 of these incidents were major category 1 incidents (incidents involving inter alia; fish kill, or closure of potable water source, or had a significant adverse effect on an area of conservation importance.)

These incidents occurred more or less evenly across all regions of England and Wales. The sources of pollution are categorised by the Agency. These categories comprise of agriculture, industrial, sewage and water industry, transport and other sources.

The Construction Industry is included within the 'industrial' category and data analysis shows that this category was responsible for $19 \%$ of the total of all substantiated incidents.

The Report (Environment Agency 1997) further sub-categorises the type of pollutant in each category. The sub-categories comprise fuels and oils, sewage, chemicals, organic wastes and others. The largest number of all substantiated incidents $(5,542)$ was represented by the 'Fuels and Oils' sub-category and most major incidents were shown to emanate from this sub-category.

It is possible to extract from the report which specific sectors of the 'industrial' category are responsible and for how many pollution incidents.

Figure 1 indicates the incidents in 1997 by source and number 


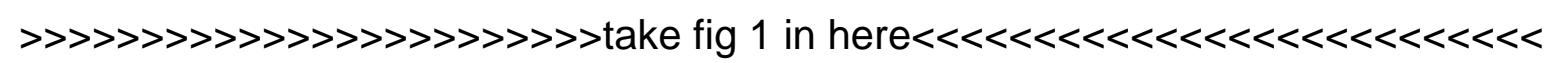

Clearly the construction industry was the most frequent polluter contributing to 588 separate incidents or $22 \%$ of the total within the industrial sector. The construction industry-related incidents are $64 \%$ higher than the next substantial contributors - the food industry.

In 1997 there were 5,542 substantiated pollution incidents nationally involving 'fuels and oils' (28\% of all substantiated incidents). Of these diesel engine oil (DERV) was the most common pollutant type, responsible for $35 \%$ of the total. However, in no less than 1,555 cases (28\%) the type of oil was either unknown or unclassified.

The Agency's report does not directly connect the construction industry with substantiated individual oil-related pollution incidents. However, given the data in the Report the following points can be highlighted from which certain assumptions and deductions may have to be made and conclusions drawn. 
1. The Industrial sector is the sector responsible for most pollution incidents.

2. The construction industry is included in the industrial category.

3. The construction industry was responsible for more substantiated pollution incidents (22\%) in the Industrial sector than any other.

4. The construction industry was singled out for criticism by the Environment Agency for being "the most frequent polluter" with an average of two pollution incidents a day being caused during construction related activities.

5. Construction-related pollution incidents showed an increase during 1997 of $15 \%$ from the previous year.

6. Mineral oil-related products accounted for more substantial incidents than any other by type in 1997 .

7. A significant percentage (28\%) of all substantiated oil-related incidents originated from unknown or unclassified types of oil. 
8. The Agency does not identify hydraulic oil as a potential source of pollution in its own right.

There is sufficient evidence to prove that the fuels and oils commonly used by the construction industry are significant polluters of the environment.

A conclusion can be drawn that some of the unknown or unclassified oils by type will be mineral-based hydraulic oils and that some of that oil will probably emanate directly from construction-related activities.

A further source of information is the oil industry itself. A significant 'player' in the oil producing industry being ESSO Lubricants. In their marketing brochure (UNIVIS BIO SHP46) they state that there is concern over (the) potential damage to the environment particularly relating to the use of hydraulic fluids. This concern stems from the vast volume of these oils a substantial amount of which is used in the hydraulic systems of construction related mobile plant and equipment, and which are apparently lost to the environment each year due to leakage or spillage.

ESSO estimates that the EU produces approximately 400 million litres of mineralbased hydraulic fluids annually of which an estimated 75\% (300 million litres) are not recycled and therefore remain unaccounted for.

\section{The case for investigation.}

Hydrocarbon-based hydraulic fluid is used in the hydraulic systems of tracked excavators. Since the 1960's tracked derivatives have been increasingly used on almost all construction sites in order to increase site efficiency and productivity. 
The evidence clearly indicates that the construction industry is a major polluter, and since the construction industry is a major user of hydraulic fluid that this potential pollutant warrants further investigation.

ESSO does not provide detailed analysis to substantiate its findings or the geographical location of the losses; nonetheless it is a public pronouncement of a highly reputable oil company acknowledging that hydraulic fluid represents a potentially serious environmental problem.

\section{Hydraulic oil systems installed in construction plant and their environmental} impacts.

The hydraulic system as installed and operated on most tracked construction plant is an external system with exposed and often unprotected flexible hoses, rigid tubes and cylinders all of which operate under high pressure and elevated temperatures. These can easily be damaged or fail during service. Badly connected or maintained hose connectors can also be a source of leakage. If a system failure occurs, large amounts of oil escape rapidly and may cause serious pollution especially in a fast flowing river, estuarine or coastal environment where the spillage may be extremely difficult or even impossible to contain.

Mineral-based hydraulic oil is highly toxic to both flora and fauna and is not readily biodegradable. As indicated by ESSO (UNIVIS BIO SHP46) much of the unaccounted for annual 300 million litres of oil may find its way into the earth, surface or sub-surface watercourses and eventually into the sea, and remain there for many years. Its chemical characteristics make hydraulic oil a particularly searching and damaging pollutant. 
As little as five litres of oil are sufficient to contaminate a small lake (National Grid Group 1998). It spreads across the surface, restricting oxygenation of the water and coating plants and animals.

It is estimated that about $45 \%$ of the oil in the seas emanates from rivers which are themselves polluted and some types of pollutant causes disease in aquatic animals which can then get passed onto humans in the food chain. If humans ingest an infected piece of food they may become very ill (Smith 1995). Similarly the proceedings of the Indonesian Petroleum Association's first annual convention as far back as June 1972 commented that depending upon the concentration of the (oil) pollutant and its duration, it can result in biological changes and changes in the ecology of the sea and coastal areas. This sort of biological damage can have severe and long-term economic consequences (Indonesian Petroleum Association).

\section{Biodegradable hydraulic oil as an alternative.}

As indicated above, this paper concentrates upon hydraulic oil as a potential point source of pollution on the basis of the available data.

Further investigation and research may help to confirm the conclusions drawn from

the data already available, and mineral-based hydraulic oil may be found to be a particularly aggressive and wide-spread polluter, especially in situations where any spillage from construction plant can find its way into a fast flowing water course. 
Oils in general are, of course, major polluters on a macro-scale. Evidenced is provided by the Exxon Valdez tanker disaster in Alaska, the Torrey Canyon off the south coast of England in 1967 and more recently the Texaco-owned 'Sea Empress', which ran aground off Milford Haven in February 1996, spilling 70,000 tonnes of crude oil into the sea. There is a broad similarity to the effects of the pollution, although hydraulic oil spills are by their nature concentrated in a much smaller geographical area. The damaging effects on the local eco-system are, however, no less serious.

Biodegradable and non-toxic oil is an alternative lubricating oil to mineral oil. According to Schofield (1997), biodegradable oil can either be 'natural' animal-based oil (fish oil, lard oil, penguin oil, whale oil) or, for continuously available high volume consumption in applications such as plant hydraulic systems, vegetable-based using oils derived from rape seed, soybean, high oleic sunflower seeds, palm oil, castor oil, or linseed oil. Alternatively it may be 'synthetic' oil, which is derived from the distillation and extra refining of mineral oil but with the addition of a number of oilsoluble additives. (Schofield 1997)

Both natural and synthetic oils, unlike pure mineral oil, contain high amounts of oxygen in their chemical structures. This can be rapidly broken down into alcohols and acids and easily digested when attacked by micro-organisms under aerobic conditions.

Biodegradable products are readily decomposed into small units and are referred to as 'readily biodegradable'. They are consequently much more environmentally 
acceptable. Mineral oils are highly toxic and not readily biodegradable, but these are the oils traditionally used by most original plant equipment and component manufacturers.

\section{The supply of non-toxic biodegradable oils - a Client's perspective.}

Few if any construction plant purchasers or users are likely to have the necessary facilities, or finances to undertake their own tests for the suitability and acceptability of oils on offer. Additionally, the prohibitive costs of research and development, combined with the relative 'newness' of biodegradable hydraulic oils available for the construction-plant market is a deterrent. Consequently, purchasers are entirely dependant upon the manufacturers, suppliers and / or distributors certifying that their oils are fully compliant with all relevant OECD and CEC criteria in terms of biodegradability and toxicity. Also that they have the unqualified approval of all relevant original plant manufacturers (OEMs) to ensure the oil's continued 'fitness for purpose' in operational service thus not invalidating any OEM warranties and guarantees.

The environmental impacts of both degradable and non-degradable oil can be assessed and measured under a series of methods established by the Co-ordinating European Council (CEC) the Environmental Protection Agency (EPA), the Organisation for Economic and Cultural Development (OECD) and to a lesser extent British Standard 7750. 
ESSO Lubricants, Texaco Oils Limited and ECO-Lube (Panolin) Limited amongst others produce non-toxic, biodegradable hydraulic oils which comply with a series of tests developed by the Organisation for Economic and Cultural Development (OECD) (test numbers 201, 202, 203 \& 301B) and which will reduce the risk of longterm damage to the environment in the event of a spillage. They claim that these oils do not compromise quality or the performance of the machine in which they are used.

At this point in time there are, however, fewer than 15 companies throughout the United Kingdom able to offer a nation-wide service for the manufacture, supply or distribution of biodegradable hydraulic oils. Fewer still can offer unequivocal evidence that the usage of their own brand of biodegradable oil in a machine will not invalidate the warranties and guarantees of world-wide Original Equipment (O.E.) plant and equipment manufacturers.

\section{Unit cost and whole life cost considerations.}

Traditionally the low sales pattern for biodegradable oils and lack of certainty in performance, has resulted in low demand and subsequently high unit price per litre when compared to an equivalent mineral-based oil. It still leaves the need to test the oil with the oil supplier and /or plant manufacturer. Current costs per litre in a 205litre barrel of synthetic oil are on average some $500-800 \%$ more expensive to purchase in the UK, and vegetable-based biodegradable oils are some $400-600 \%$ more expensive than equivalent mineral oils. (Eichenberger 1991) 
ESSO Lubricants (ibid.) state that the main disadvantage of synthetic ester based fluids is cost and Eichenberger (of Caterpillar Overseas S.A.) stated that the costly conversion from mineral to biodegradable oils will cause the cost of building materials to go up. He also stated that he felt that it would be worth it for a better environment and that (significantly) the superior performance and longer life of these (synthetic oil) products outweighs the high cost.

There is evidence, therefore, that as well as being environmentally friendly these synthetic biodegradable oils could have real purchase (whole life cost) benefits too.

ESSO Lubricants (UNIVIS BIO SHP46) claim that synthetic ester-based hydraulic fluids exhibit superior performance over premium mineral oils, including:

- $\quad$ excellent rust and corrosion protection

- $\quad$ excellent low temperature characteristics offering improved cold temperature start up

- $\quad$ outstanding performance in conditions where superior load carrying and extreme pressure are necessary

- $\quad$ good demulsibility giving good water separation properties

- $\quad$ good compatibility with existing mineral-based hydraulic oils

- $\quad$ energy savings of up to $6 \%$ on hydraulic pump operation

- $\quad$ excellent Health and Safety record

- $\quad$ superior oxidation stability giving longer service life and needing fewer oil changes 
Indeed, according to Texaco Oils Limited, there is no reason why synthetic oil, apart from regular top ups, should not last the life of the machine.

If these benefits are achievable then the savings associated with the ability to avoid regular replacement of mineral oil, disposal costs of the old oil and filters, replacement of worn parts, labour costs during service and maintenance, operations and production downtime costs suggest that a life cycle cost view of using these oils is well worthwhile.

Purchasers of plant may not always adopt a whole-life approach with regards to hydraulic oil. In a highly competitive market they will tend to focus on price. There is little incentive (in a business sense) for O.E. manufacturers to take a more environmentally friendly stance unless the pressure comes from the buyers, clients or customers of their plant or government legislation affects the buyers or the endusers of their plant or equipment.

\section{Methodology adopted in the investigation}

Attitudes to the environment do change over time without legislation and may often be driven by clients, companies or organisations wishing to present a 'greener' image to its customers in order to gain a competitive advantage in a market place.

To enable the implication of corporate policy regarding the adoption of environmentally friendly oils and at the same time to establish the validity of data already collected about biodegradable oils a questionnaire was sent to a number of 
construction companies across England and Wales. In particular 23 companies were selected for close scrutiny as they had applied to an advertisement placed by the Environment Agency in a national contracting journal. The advertisement invited contractors to express an interest in carrying out a range of civil engineering related projects in and around watercourses. The purpose of the questionnaire was to evaluate amongst other issues, each company's attitude and approach to its environmental duty and responsibilities. The responses would be a key element in a range of predetermined criteria against which each company would be compared and evaluated in order to establish their overall suitability to meet the Environment Agency's requirements and to be included on a select list to receive tenders. Individual Company size varied by annual turnover from $£ 5$ million to $£ 600$ million and coincidentally about half of the companies analysed appeared in a list of 'Top 50' UK construction companies by value of awards in 1998 (Contract Journal January 1999).

Since those companies appearing in the 'Top 50' list had a collective value of contracts awarded of about $£ 3.625$ billions it seems safe to assume a total turnover of $£ 4$ billions may be accounted for by the sample - nearly one third of all contracts let in 1998.

A case study approach was also adopted in relation to two civil engineering projects. Both of which were directly adjacent to open watercourses (rivers) in the North West of England.

Particular issues to be addressed were: 
- $\quad$ whether the reality of using biodegradable oil on site was consistent with perceptions?

- $\quad$ whether logistical problems are likely to hinder the adoption of an implementation policy relating to biodegradable oils?

whether site-based investigations confirm the reported incidence of oilbased pollution when related to civil engineering projects close to water courses

The construction organisations involved with these projects were on the one hand, the Environment Agency and on the other a major UK construction company.

The first case study project was situated at the confluence of the Rivers Douglas and Yarrow in Central Lancashire. This involved work relating to maintenance and repair of flood defence embankments. The area is one of great importance to the local farming economy and one of environmental sensitivity.

The second case study project involved a flood alleviation scheme on the River Etherow designed to prevent the frequent recurrence of large-scale flooding to arterial road networks, private and industrial and commercial property in the Derbyshire town of Glossop. The river at the point of the work is narrow and often fast flowing, carrying water as it does to large downstream reservoirs serving drinking water to Greater Manchester.

If oil spillage were to take place at either site it would be a major environmental incident.

In each case site-based staff were interviewed to discover how any policy to use biodegradable oil would be accepted at site level. 


\section{Results from the questionnaire}

Table 1 below indicates the questions asked of the contractors and an analysis is shown. There was a $100 \%$ response to the questionnaire (probably because of the benefits, which may be accrued from working with a prestigious and highly reputable UK Client).

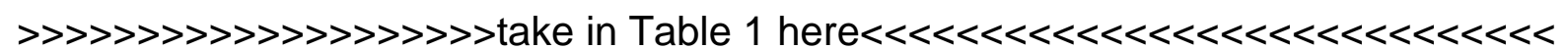


Analysis of the responses to the questionnaire indicates consensus in their commitment to the development of policies to achieve continued improvement in terms of the environment. Relatively high compliance is shown in terms of appointment of a Director with specific responsibility for environmental performance. Less positively these companies largely fail to set environmental objectives or targets or to publicly report on them.

A significant majority of these companies selected and/or monitored their own suppliers and subcontractors and showed commitment to seeking continued improvement. As few as 22\%, however, had formal quality assurance or ISO 9000 registration.

Analysis of the case studies indicates that one site had already adopted a policy of always using biodegradable oil; the other had not but "were considering it". The Environment Agency had clearly identified by externally colour-coding its own tracked excavators and had found that due to less servicing and less oil changes the extra cost per litre of the oil was not adding to the cost of using the machine during construction operations.

The other site was concerned that machines must pay their way and took the view that if the client was not insistent they would probably stick with the (cheaper) existing mineral oil.

Interestingly the manager of this site accepted that probably as individuals, plant operatives might not fully understand the need to protect the environment and avoid pollution wherever possible.

Managers of both sites recognised that notwithstanding any corporate policy the occasional need to 'spot hire' from specialist plant-hire companies on an emergency 
or one-off basis may compromise any such policy. Whilst neither interviewee admitted that they had had a problem of oil pollution the construction company admitted that $95 \%$ of its plant servicing was done on site.

The Environment Agency site ensured that a designated area was used and that both the plant operator and the service mechanic were appropriately trained in the handling and usage of synthetic hydraulic oil.

From the answers given the overall conclusion reached is that given sufficient and adequate levels of communication the logistical problems involving the application, usage and segregation of biodegradable oils from ordinary mineral oils at site level are not insurmountable.

\section{Biodegradable oils and the Construction Industry}

The responses to the questionnaire and the indications from the case studies seem to indicate a willingness to adopt a positive attitude towards issues relating to the environment. This is especially the case where a specific or implied client requirement exists, but there was less evidence of a proactive and innovative environmental approach within the companies themselves.

The Environment Agency followed up the questionnaire with a request for further unique and specific information from each of these individual companies. This information was provided in the form of an 'Environmental Policy'. 
Some key points emanating from a detailed analysis of the statements made within each of the policies included: -

- most companies included a statement of preventative actions to be taken when working in a location that had the potential to pollute a watercourse.

- all referred to the potential environmental hazards relating to the use and storage of fuel (oils) and the need to reduce the risk of pollution incidents, although only three companies acknowledged the use of hydraulic oils within on-site plant and equipment and only one of those recognised hydraulic oil as a potential pollutant.

- some referred to the need for regular maintenance checks intended to anticipate or prevent oil leakage from plant and equipment

- all acknowledged the universal need to observe full compliance with relevant environmental legislation and statutory regulations to prevent and avoid pollution.

- none of the environmental policies referred to the usage of non-toxic biodegradable oils, or other materials as a means of preventing site-based pollution incidents. 
Plainly there seems to be a large amount of mineral hydraulic oil unaccounted for. Synthetic non-toxic and biodegradable hydraulic oil is an acceptable alternative, but there is no clear evidence from the data collected that the use of this alternative is as yet high on the environmental policy of any major UK construction company. Under the circumstances it would appear that the adoption of alternative hydraulic oils might have to be driven by either construction-client customers or legislation and regulation.

\section{Influences on the decision-making process.}

At this point it may be appropriate to give a more detailed review of the likely acceptability of alternatives to mineral-based hydraulic oils.

The performance which ESSO claims for its biodegradable oil is referred to above, but TEXACO has also conducted tests on its 'Hydra 46' synthetic hydraulic fluid. It claims that it can see no reason why, apart from regular top ups, that the factory filled oil should not last the life of the machine provided that it is regularly maintained in accordance with the Original Equipment Manufacturer's (OEM) and oil supplier's recommendations.

An analysis of the detailed specifications of these oils and a review of the oil's availability in Table 2 outlines both the potential advantages and possible disadvantages to the 'end user' of the use of synthetic biodegradable oils when compared to a mineral-based equivalent. 


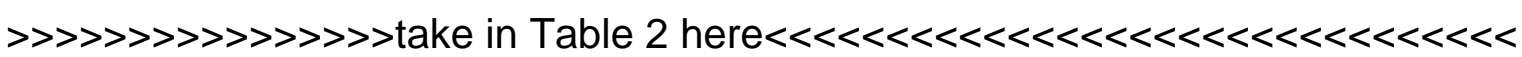


From an objective appraisal of the advantages and disadvantages identified in the table 2 it may be difficult for a plant owner / operator to argue that the disincentives for change or disadvantages of using an environmentally considerate lubricant outweigh the advantages.

A range of other issues which have deliberately not been considered or discussed within the scope and context of this paper but which may in themselves play an equal or arguably more important role in a company's environmental decisionmaking process could include amongst others:

- stakeholder pressure

- lobbying from 'Green' groups

- desire to improve the company's image

- $\quad$ pressure from national and international clients

- fear of the effects of adverse publicity

- lack of environmental awareness and education

- reduced operational cost competitiveness / operational cost increases.

- ability to obtain certain type of work in previously off-limit locations such as Sites of Special Scientific Interest.

- fines resulting from breaches of environmental legislation and subsequent costs of reinsurance.

- Political pressures.

- Inability to raise financial backing or obtain insurance cover after repeated pollution incidents and subsequent prosecutions for breaches of environmental legislation. 
It could be argued that from a financial investment point of view the day-to-day cost of using synthetic biodegradable hydraulic oil is at best 'cost neutral'. On the other hand if taken in the context of the risks to the environment as a whole and to the financial costs to the Company Organisation in the short-term e.g. as a direct result of the pollution 'clean-up' after a spillage and subsequent court-costs and fines in addition to the bad publicity and potential loss of business goodwill in the long-term, then the overall cost is nothing less than 'cost negative'.

It may be some or all of the above factors will interact to influence a staged change to the usage of biodegradable oil.

\section{Legislation and legal incentives to change.}

A review of the current position of one of these factors - legislation - indicates that extensive and robust legislation designed to protect the environment already exists under both European and UK law. In 1997 the Environment Agency successfully prosecuted and brought about 67 convictions with fines ranging up to $£ 12,000$ (plus costs) for individual incidents. There was a $100 \%$ success rate by the Agency for prosecutions in oil-related pollution incidents. The Courts have also increasingly adopted a 'polluter pays' policy in prosecution cases in line with Government guidelines and the costs of 'clean up' both of direct fines and indirectly through adverse publicity and loss of business can be very high for those convicted.

The Pollution Prevention and Control Bill was due to complete its passage through Parliament in October 1999 It is designed to "prevent, reduce and eliminate pollution 
at source through the prudent use of natural resources" and to "help industrial operators move towards greater environmental sustainability". The effect of this bill will be to strengthen, enlarge and widen environmental legislation as a means to control pollution.

In addition to the more obvious financial penalties imposed through the Courts, the adverse publicity associated with environmental pollution can result in other companies or organisations becoming reluctant to trade or do business or be associated with convicted 'polluters' with the inevitable economic consequences on the guilty party.

Current European or UK legislation, however, falls short of direct and clear-cut legislation to enforce the use of biodegradable oils in place of mineral-based oils.

Consequently the application of current legislation to control site-based pollution in the context of biodegradable oils may depend upon its interpretation by the magistrates to whom prosecutions are directed.

Alternatively the responsibility falls upon the construction client to enforce the usage of environmentally considerate lubricants.

\section{A Client enforcing the usage of environmentally considerate lubricants}

An example of a client taking this position is The Environment Agency itself. In seeking to achieve its statutory duties of protecting and enhancing the environment it 
also acts as a major construction client in its own right. With a capital budget of $£ 1.3 \mathrm{bn}$ over the next 10years on a range of civil engineering-related riverine, estuarine and coastal flood-defence works across England and Wales, it accounts for about $2 \%$ of the UK's annual civil engineering industry turnover.

The Environment Agency also owns and operates a fleet of more than two hundred heavy $360^{\circ}$ tracked excavators, each of which uses hydraulic oil. In June 1997 they implemented an eight-year rolling programme to replace all of its fleet by the year 2005 with brand new machines and to fill the hydraulic systems of all newly purchased machines only with synthetic biodegradable oil.

It has subsequently given notice by amendments to its technical specifications and in a high profile nation-wide publicity campaign targeted at construction and all related industries that from June 2005 onwards all contractors, sub-contractors, plant-hire companies or any company or organisation wishing to contract with it for works in or adjacent to a watercourse must use only tracked excavators pre-filled with an approved biodegradable oil. Failure to comply with that requirement will result in the 'Contractor' being requested to remove his machine(s) from site.

Almost all other large construction clients now have some form of commitment in their environmental policy to managing environmental risk. Consequently there are now an increasing number of examples of influence on supply chains towards a more environmentally considerate approach, although this is arguably the most unique, influential and far-reaching within the British construction industry. 


\section{Conclusions}

Data shows that the Construction Industry in the UK is without doubt responsible for the largest number of all substantiated pollution incidents within the category classed by the Environment Agency as the 'industrial' sector. The construction industry is a major user of plant and machinery and is thus a major consumer of mineral oil-based hydraulic fluids. Mineral oils are highly toxic and particularly polluting, especially in open watercourses such as rivers, lakes, ponds and reservoirs. The hydraulic fluid, which is generally supplied by default in new construction machinery from the factories and is replaced during servicing throughout the life of the machine has a mineral-oil base and is an aggressive pollutant.

It is estimated that 400 million litres of hydraulic fluid are produced annually throughout the EU and of that, 300 million litres remain unaccounted for and are presumably lost to the environment. Hydraulic oil is consequently a significant pollutant.

The synthetic non-toxic biodegradable oil accepted for use by the Environment Agency over the last three years is far more environmentally considerate and is now being produced by a limited number of international companies. It passes all current OECD and CEC environmental tests and has no detrimental effects on the hydraulic performance of the plant and machinery and does not invalidate OEM warranties. It is however about six times more expensive per litre to buy than an equivalent mineral oil. 
Such is the size of the task which the Environment Agency took on board in mid1997 that even the impressive claims for the environmental and life-cycle benefits of synthetic biodegradable hydraulic oil have been slow to impress the plant manufacturers or users.

Although the usage of non-toxic biodegradable hydraulic oil is not specifically identified, newly implemented EU and UK environmental legislation requires the construction industry to look in ever-increasing detail at all aspects of its activities and the resulting impacts upon the environment.

For those enlightened companies who take the legislation on-board in the spirit with which it is intended and see it as a business opportunity rather than a business threat, it can bring considerable financial and long-term benefits. Sadly there are still many companies who remain ignorant of the law or who don't or won't comply. In those cases the net is closing in and legislation seems as though it will be rigorously enforced. The consequences in financial and business terms for those prosecuted and convicted of breaches of environmental law are becoming increasingly punitive. Corporate organisations or individual Clients of all sizes within the construction industry with a policy or mission to 'work with' or protect the environment should ensure that through their own supply-chain management or specification development that environmentally considerate hydraulic oils form part of their collective 'global' standards wherever and whenever applicable.

The annual turnover within the construction industry represents about $9 \%$ of the UK's G.D.P. It is a significant extractor and consumer of natural resources. Its day-to-day activities can have a huge and long-term impact upon the environment not only in 
the UK but also on a worldwide scale. It has therefore a major responsibility to adhere to the principles of sustainable development and to reduce the risks and minimise its impacts on the environment at all times.

The construction industry has a vital role to play in the economy of the country but at the same time poses many different and significant threats to the environment. Each one of which must in turn be analysed, evaluated and reduced or eliminated wherever possible. Oil-based pollution from construction sites is one of those threats.

The usage of synthetic non-toxic biodegradable hydraulic oils in construction plant and machinery would be another step in the right direction. 
Report of the Environment Agency.1997., Water pollution incidents in England and Wales 1997; The Stationery Office, London.

ESSO Lubricants: UNIVIS BIO SHP46; Biodegradable Synthetic Hydraulic Oil: Marketing Brochure.

The National Grid Group plc. 1998., Annual Review 1997/98.

http://science.cc.uwf.edu/sh/curr/waterpollution/water.htm (Smith, G : University of West Florida, December 8, 1995) Water Pollution - Sources of Water Pollution.

http://www.ipa.or.id/197214ipa72.htm (Indonesian Petroleum Association): The Role of Man and Technology in facing the challenge of Pollution.

Schofield, Professor J., 1997., Biodegradables "they cost the earth": The 1997 Donald Julius Groen Prize lecture; Liverpool John Moores University December 1997.

Eichenberger, H.F., 1991., Biodegradable Hydraulic Lubricant, an overview of current developments in Central Europe. SAE Technical Paper series 910962: 42nd Earthmoving Industry Conference, Peoria, Illinois, USA. 


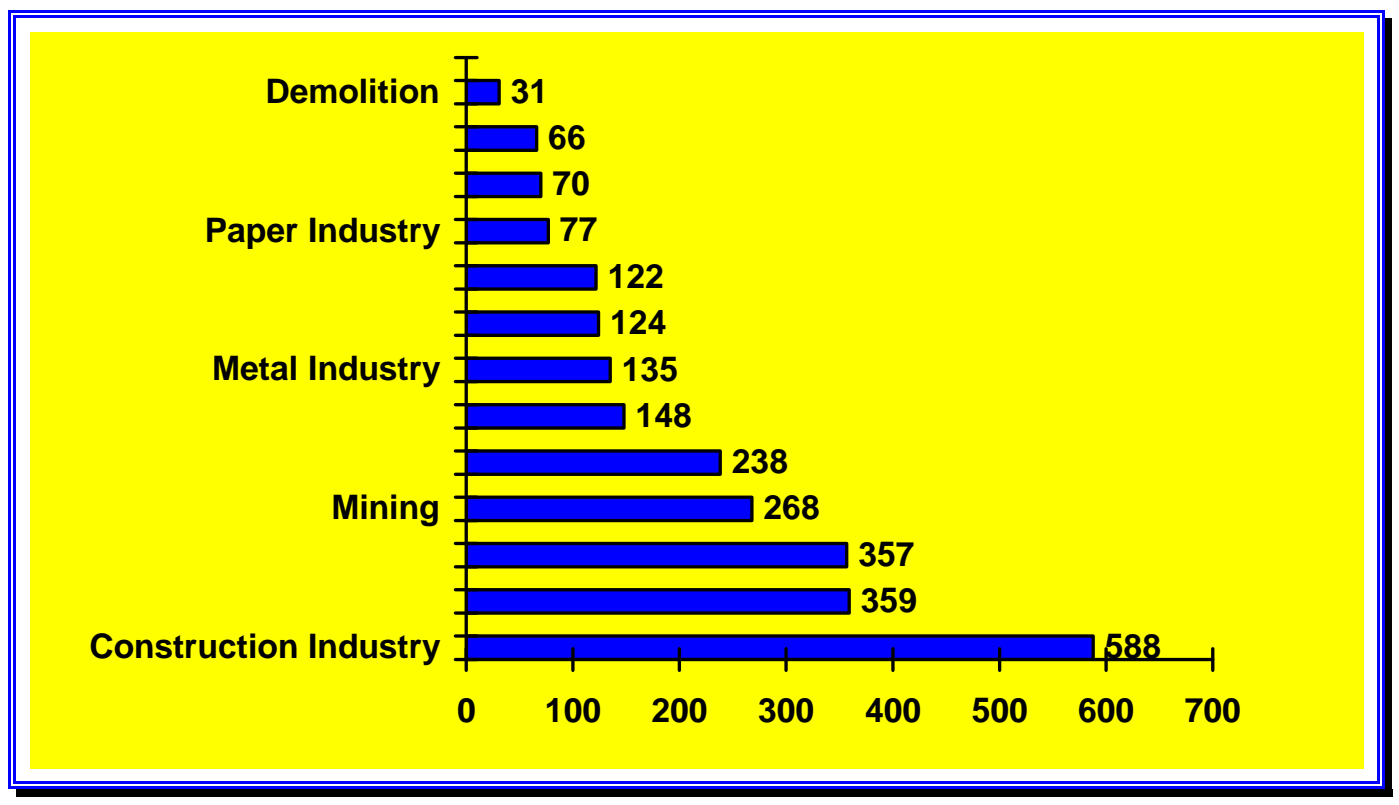

Source: Water pollution incidents in England and Wales 1997. The Environment Agency 1997.

Figure 1 
Table 1 : Analysis of questionnaire results

\begin{tabular}{|c|c|c|c|c|c|c|c|}
\hline & QUESTION. & $\begin{array}{l}\text { Number of } \\
\text { responses }\end{array}$ & $\begin{array}{l}\text { Respon } \\
\text { se rate }\end{array}$ & $\begin{array}{l}\text { Number of } \\
\text { compliant } \\
\text { responses }\end{array}$ & $\begin{array}{c}\text { Percentage } \\
\text { compliant }\end{array}$ & $\begin{array}{c}\text { Number of } \\
\text { non- } \\
\text { compliant } \\
\text { responses }\end{array}$ & $\begin{array}{c}\text { Percentage } \\
\text { non- } \\
\text { compliant }\end{array}$ \\
\hline 1. & $\begin{array}{l}\text { Does your Company have } \\
\text { formal BS } 5750 \text { / ISO } 9000 \\
\text { certification or registration? }\end{array}$ & 23 & $100 \%$ & 5 & $22 \%$ & 18 & $78 \%$ \\
\hline 2. & $\begin{array}{l}\text { Does your Company select/ } \\
\text { monitor its suppliers and sub- } \\
\text { contractors of goods and } \\
\text { services in order to meet } \\
\text { your own standards and quality } \\
\text { requirements? }\end{array}$ & 23 & $100 \%$ & 21 & $91 \%$ & 2 & $9 \%$ \\
\hline 3. & $\begin{array}{l}\text { Can you describe how your } \\
\text { Company is committed to } \\
\text { continued improvement in terms } \\
\text { of its design, products or } \\
\text { services? }\end{array}$ & 23 & $100 \%$ & 23 & $100 \%$ & 0 & $0 \%$ \\
\hline 4. & $\begin{array}{l}\text { Does your Company have a } \\
\text { Director with specific } \\
\text { responsibility for the } \\
\text { environmental performance of } \\
\text { the Company? }\end{array}$ & 23 & $100 \%$ & 21 & $91 \%$ & 2 & $9 \%$ \\
\hline 5. & $\begin{array}{l}\text { Does your Company have a } \\
\text { policy committing it a } \\
\text { programme of continued } \\
\text { environmental improvement? }\end{array}$ & 23 & $100 \%$ & 23 & $100 \%$ & 0 & $0 \%$ \\
\hline 6 & $\begin{array}{l}\text { Does your company have an } \\
\text { Environmental (BS/EN/ISO } \\
\text { 14000) Management System? }\end{array}$ & 23 & $100 \%$ & 1 & $4 \%$ & 22 & $96 \%$ \\
\hline 7 & $\begin{array}{l}\text { Does your Company set } \\
\text { environmental performance } \\
\text { targets and objectives? }\end{array}$ & 23 & $100 \%$ & 9 & $39 \%$ & 14 & $61 \%$ \\
\hline 8. & $\begin{array}{l}\text { Does your Company publicly } \\
\text { report on progress and } \\
\text { achievement of these } \\
\text { objectives? }\end{array}$ & 23 & $100 \%$ & 3 & $13 \%$ & 20 & $87 \%$ \\
\hline 9. & $\begin{array}{l}\text { Has your Company been } \\
\text { successfully prosecuted on } \\
\text { grounds of breach of } \\
\text { environmental legislation in the } \\
\text { last three years? }\end{array}$ & 23 & $100 \%$ & 4 & $17 \%$ & 19 & $83 \%$ \\
\hline
\end{tabular}


Table 2: $\quad$ Advantages and disadvantages to the 'end-user' of synthetic biodegradable oils when compared to mineral oil equivalent.

\begin{tabular}{|c|c|}
\hline Advantage & Disadvantage \\
\hline $\begin{array}{ll}- & \text { complies fully with existing pollution } \\
& \text { control and environmental legislation. }\end{array}$ & $\begin{array}{l}\text { inability of client to undertake own fitness for } \\
\text { purpose trials; reliant on supplier data. }\end{array}$ \\
\hline $\begin{array}{l}\text { - } \text { meets with the spirit of public \& political } \\
\text { pressure to avoid pollution. }\end{array}$ & $\begin{array}{l}\text { no globally accepted standards as yet for } \\
\text { testing of overall environmental performance }\end{array}$ \\
\hline $\begin{array}{l}\text { reduced risk of pollution to a watercourse } \\
\text { and consequential long-term damage to } \\
\text { the local eco-system and environment in } \\
\text { general. }\end{array}$ & $\begin{array}{l}\text { difficult to be absolutely sure that all major } \\
\text { O.E.M guarantees and warranties will not be } \\
\text { invalidated. }\end{array}$ \\
\hline $\begin{array}{l}\text { reduced risk of financial punishments, } \\
\text { court case costs and costs incurred to } \\
\text { 'clean-up' after an incident. }\end{array}$ & $\begin{array}{l}\text { environmental benefits are much reduced if } \\
\text { the oil is cross-contaminated with more than } \\
5 \% \text { mineral oil e.g. occurs when changing } \\
\text { machine arms. }\end{array}$ \\
\hline $\begin{array}{l}\text { - } \begin{array}{l}\text { reduced risk of adverse publicity and } \\
\text { potential negative affect on future } \\
\text { business. }\end{array} \\
\end{array}$ & $\begin{array}{l}\text { - relatively few supply sources in the UK may } \\
\text { lead to lack of price competition. }\end{array}$ \\
\hline $\begin{array}{l}\text { - can be used as a potential marketing 'tool' } \\
\text { when applying for works in UK and } \\
\text { mainland Europe. }\end{array}$ & $\begin{array}{l}\text { - } \quad \text { no financial or legislative incentive to } \\
\text { implement an oil-change programme. }\end{array}$ \\
\hline $\begin{array}{ll} & \text { equal or better technical operating } \\
& \text { performance and load-carrying capacity }\end{array}$ & $\begin{array}{l}\text { - } \quad \text { non-miscible with poly (ethylene glycol) } \\
\text { based hydraulic fluids. }\end{array}$ \\
\hline $\begin{array}{l}\text { - reduced 'down-time' during routine plant } \\
\text { maintenance. }\end{array}$ & $\begin{array}{l}\text { - machine system must be well maintained to } \\
\text { OEM standards to prevent ingress of water. }\end{array}$ \\
\hline $\begin{array}{l}\text { miscible with existing mineral based } \\
\text { hydraulic oils; can be retro-fitted into } \\
\text { existing hydraulic systems if existing } \\
\text { system is 'flushed' correctly. }\end{array}$ & $\begin{array}{l}\text { oil samples must be tested in an expert } \\
\text { laboratory for condition monitoring on a } \\
\text { regular basis and at plant-owner's expense. }\end{array}$ \\
\hline $\begin{array}{l}\text { - wider range of operating temperatures } \\
\text { typically }-35^{\circ} \text { to }+90^{\circ}\end{array}$ & $\begin{array}{l}\text { - } \text { gross water contamination can lead to } \\
\text { system failure. }\end{array}$ \\
\hline $\begin{array}{l}\text { - } \begin{array}{l}\text { energy saving during operation of } \\
\text { hydraulic pumps }\end{array} \\
\end{array}$ & $\begin{array}{l}\text { - high level of financial investment if converting } \\
\text { large fleet of plant. }\end{array}$ \\
\hline $\begin{array}{l}\text { - excellent rust and corrosion protection to } \\
\text { the hydraulic system. }\end{array}$ & $\begin{array}{ll} & \text { high unit price per litre compared to } \\
& \text { equivalent mineral based oil }\end{array}$ \\
\hline $\begin{array}{ll}\text { - } & \text { current market demand does not outstrip } \\
\text { supply }\end{array}$ & \\
\hline - readily biodegradable. & \\
\hline $\begin{array}{l}\text { - excellent health and safety performance; } \\
\text { non-toxic to humans. }\end{array}$ & \\
\hline - non-toxic to flora and fauna. & \\
\hline $\begin{array}{l}\text { - } \quad \text { no requirement for any physical or } \\
\text { technological modifications to the } \\
\text { machine. }\end{array}$ & \\
\hline - $\quad$ extended service \& maintenance intervals & \\
\hline $\begin{array}{l}\text { - } \begin{array}{l}\text { savings on labour costs \& regular need to } \\
\text { replace and reprocess old mineral oil. }\end{array} \\
\end{array}$ & \\
\hline
\end{tabular}

